\title{
Response of Fumaric Acid Addition on Methanogenesis, Rumen Fermentation, and Dry Matter Degradability in Diets Containing Wheat Straw and Sorghum or Berseem as Roughage Source
}

\author{
S. K. Sirohi, Poonam Pandey, and Navneet Goel \\ Nutrition Biotechnology Laboratory, Dairy Cattle Nutrition Division, National Dairy Research Institute, Haryana 132001, India \\ Correspondence should be addressed to S. K. Sirohi, sirohisk@gmail.com
}

Received 18 November 2011; Accepted 18 December 2011

Academic Editors: M. Albenzio and W. Yang

Copyright () 2012 S. K. Sirohi et al. This is an open access article distributed under the Creative Commons Attribution License, which permits unrestricted use, distribution, and reproduction in any medium, provided the original work is properly cited.

\begin{abstract}
An in vitro incubation system was used to evaluate effect of supplementation of fumaric acid at $0,5,10$, and 15 mM concentration in high-, medium-, and low-fiber wheat straw containing total mixed diets with sorghum (Sorghum vulgare) and berseem clover (Trifolium alexandrinum L.) on rumen fermentation, methane production, and gas kinetics parameters. Three types of diets were prepared with different roughage and concentrate ratio $(80: 20,50: 50$, and $20: 80)$ by taking the representative samples. The roughage part composed of wheat straw (70 parts) and sorghum (30 parts) or berseem ( 30 parts) and the concentrate part composed of maize $(33 \%)$, GNC (21\%), mustard cake (12\%), wheat bran (20\%), deoiled rice bran (11\%), mineral mixture $(2 \%)$, and salt (1\%). Fumaric acid was added in incubation medium to achieve final concentration of $0,5,10$, and $15 \mathrm{mM}$. All the treatment combinations were arranged in $4 \times 3$ factorial designs with three replicates. It was concluded from the study that fumaric acid addition $(5-15 \mathrm{mM})$ in diets varying in roughage to concentrate ratio significantly $(P \leq 0.05)$ reduced the methane production without affecting dry matter digestibility and maximum reduction was noticed at $5 \mathrm{mM}$ concentration.
\end{abstract}

\section{Introduction}

Many of compounds have been tested as potential feed additives for ruminants on the basis of their direct or indirect effects on $\mathrm{CH}_{4}$ production in the rumen. These compounds include ionophores, halogenated $\mathrm{CH}_{4}$ analogues, and unsaturated fatty acids $[1,2]$. Other approaches are to reduce protozoal population which is believed to have symbiotic relationship with methanogens by using different compounds [3]. Another strategy of diverting $\mathrm{H}_{2}$ from $\mathrm{CH}_{4}$ production is to increase alternative electron sink metabolic pathways to dispose of the reducing power [3-5]. Fumarate and malate are key intermediates in the succinate-propionate pathway, in which malate is dehydrated to fumarate and fumarate reduced to succinate, which is then decarboxylated to propionate. Reducing equivalents are consumed in the reduction of fumarate to succinate, and hence both fumarate and malate have been shown to compete successfully for in the rumen with reduced methane production both in vitro and in vivo conditions. Therefore, present study was planned to evaluate the effect of fumaric acid on diets containing wheat straw and sorghum or berseem as roughage source at different concentration generally used in Indian conditions for various categories of dairy animals.

\section{Materials and Methods}

2.1. Feeds and Experimental Design. To evaluate the response of fumaric acid, three diets were prepared by taking different roughage and concentrate ratio of $50: 50,20: 80$, and $80: 20$ on dry matter basis. The roughage part composed of wheat straw (70 parts) and sorghum (30 parts) or berseem (30 parts) and the concentrate part composed of maize (33\%), groundnut cake $(21 \%)$, mustard cake $(12 \%)$, wheat bran $(20 \%)$, deoiled rice bran (11\%), mineral mixture $(2 \%)$, and salt (1\%). Fumaric acid (Sigma-Aldrich, EC203-743-0) was added in incubation medium to achieve final concentration of $0,5,10$, and $15 \mathrm{mM}$ prepared in distilled water (DW), and required quantities in equal volumes were added in 
both control (only DW) and treatments. All the treatment combinations were arranged in $4 \times 3$ factorial arrangements in randomized block design with three replicates. A set was incubated devoid of substrate with and without fumaric acid which served as blanks for particular treatment and values were corrected for different parameters with these blanks.

2.2. Preparation of Inoculum. Rumen liquor was collected from a fistulated male buffalo maintained on a standard diet (60 parts roughage: 40 parts concentrate) before morning feeding into a pre-warmed insulated flask and brought into the laboratory. The rumen liquor was filtered through four layers of muslin cloth and then the required amount of filtered rumen liquor used as a source of inoculums. Required approval was obtained from Institutional Animal Ethics Committee prior to conduct experiments.

2.3. In Vitro Gas Production. The substrate was milled to pass through $1 \mathrm{~mm}$ sieve, and $200 \pm 10 \mathrm{mg}$ was weighed in glass syringes of $100 \mathrm{~mL}$ capacity. $100 \mathrm{~mL}$ glass syringes were used for in vitro gas production technique [6]. The $30 \mathrm{~mL}$ incubation medium was dispensed anaerobically in each syringe. Syringes were incubated at $39 \pm 0.50^{\circ} \mathrm{C}$ for $24 \mathrm{~h}$. Before incubation, fumaric acid solution injected as per the dose by small syringe into $100 \mathrm{~mL}$ syringes individually. Syringes were pre-warmed $\left(39 \pm 1^{\circ} \mathrm{C}\right)$ prior to the addition of $30 \mathrm{~mL}$ buffered rumen liquor into each syringe under $\mathrm{CO}_{2}$ flushing. Plungers of syringes were applied with petroleum jelly for smooth movement and stop any leakage. Syringes were closed using clamps and were incubated for $24 \mathrm{~h}$ in case of in vitro dry matter digestibility (IVDMD), total volatile fatty acids (TVFAs), individual volatile fatty acids (IVFAs), and methane, while incubated for $96 \mathrm{~h}$ (in sequential incubation for $0,1,2,3,6,9,12,24,30,36,48,60,72$, and $96 \mathrm{~h}$ ) in case of gas kinetics study.

2.4. Total Gas Production and Methane Estimation. After $24 \mathrm{~h}$ incubation, total gas production was estimated by the displacement of piston during incubation. The gas produced due to fermentation of substrate was calculated by subtracting gas produced in blank syringe (containing no substrate, but only the inoculum and buffer) from total gas produced in the syringe containing substrate and inoculum and buffer. For methane estimation, representative gas was sampled from the headspace of syringe in an airtight syringe and injected into Nucon-5765 gas chromatograph equipped with flame ionization detector (FID) and stainless steel column packed with Porapak-Q. The gas flow rates for nitrogen, hydrogen, and air were 30,30 , and $300 \mathrm{~mL} / \mathrm{min}$, respectively. Temperature of injector oven, column oven, and detector were 40,50 , and $50^{\circ} \mathrm{C}$, respectively. A $50 / 50$ mixture of methane and carbon dioxide (Spancan; Spantech Products Ltd., England) was used as a standard.

2.5. Partitioning Factor (PF) and Microbial Biomass Yield $(M B M)$. The PF is calculated as the ratio of substrate truly degraded in vitro $(\mathrm{mg})$ to the volume of gas $(\mathrm{mL})$ produced.
The MBM yield was calculated by using the degradability of substrate and gas volume and stoichiometrical factor [7]:

$$
\begin{aligned}
& \text { Microbial mass }(\mathrm{mg}) \\
& =\text { Substrate truly degraded } \\
& \quad-(\text { gas volume } \times \text { stoichiometrical factor }),
\end{aligned}
$$

where the stoichiometrical factor used was 2.25 .

2.6. Gas Production Kinetics. Kinetics of gas production was calculated using a nonlinear model [8]. The NLIN procedure of Sigma stat 3.11 was used to fit the following model: $p=$ $b[1-e-c(t)]$, where $p$ is the gas production rate at time $t, b$ is the potential gas production $(\mathrm{mL})$, and $c$ is gas production rate constant $(\mathrm{mL} / \mathrm{h})$ of $b$ and $t$ is the time of incubation (h). The total gas production kinetics was carried out in different treatment combinations incubated as per procedure mentioned above for different intervals that is, 0,1 , $2,3,6,9,12,24,36,48,60,72$, and $96 \mathrm{~h}$. The potential gas production and rate of gas production was calculated by fitting the modified equation [8].

2.7. Rumen Fermentation Parameters. The supernatant of each syringe including that of blank was used for $\mathrm{NH}_{3}-\mathrm{N}$ estimation. Supernatant $(5 \mathrm{~mL})$ was mixed with $1 \mathrm{~N} \mathrm{NaOH}$ $(2 \mathrm{~mL})$ and steam passed on this using KEL PLUS-N analyzer (Pelican, India), and the $\mathrm{NH}_{3}$ evolved was collected in boric acid solution having mixed indicator and titrated against $\mathrm{N} / 100 \mathrm{H}_{2} \mathrm{SO}_{4}$. TVFA concentration $(\mathrm{mmol} / 100 \mathrm{~mL}$ ) in the supernatant was estimated [9] in the supernatant. At the end of incubation $(24 \mathrm{~h}), 1 \mathrm{~mL}$ of the supernatant was treated with 25\% meta-phosphoric ( $4 \mathrm{~mL})$ and kept for 3-4 h at ambient temperature [10]. Thereafter, it was centrifuged at $3000 \mathrm{rpm}$ for 10 minutes, and clear supernatant was collected and stored at $-20^{\circ} \mathrm{C}$ until analyzed. IVFA was estimated using gas chromatograph (Nucon 5700, India) equipped with flame ionization detector (FID) and stainless steel column (length $4^{\prime}$; o.d $(1 / 8)^{\prime \prime}$; i.d $2 \mathrm{~mm}$ ) packed with chromosorb-101. Temperature of injection port, column and detector was set at 200,180 , and $210^{\circ} \mathrm{C}$, respectively. The flow rate of carrier gas (nitrogen) through the column was $40 \mathrm{~mL} / \mathrm{min}$; and the flow rate of hydrogen and air through FID was 30 and $300 \mathrm{~mL} / \mathrm{min}$, respectively. Sample $(2 \mu \mathrm{L})$ was injected through the injection port using Hamilton syringe $(10 \mu \mathrm{L})$. Individual VFAs of the samples were identified on the basis of their retention time and their concentration $(\mathrm{mmol})$ and calculated by comparing the retention time as well as the peak area of standards after deducting the corresponding blank values.

2.8. Protozoa Counting. For protozoal count, one milliliter of the fermentation fluid was diluted with $1 \mathrm{~mL}$ of formalin (18.5\% formaldehyde) and 3-4 drops of brilliant green and then incubated for 24 hours at room temperature. The stained protozoa were diluted (if needed) and counted by Haemocytometer [11]. 
TABLE 1: Chemical composition of berseem and sorghum containing diets.

\begin{tabular}{|c|c|c|c|c|c|c|c|}
\hline \multicolumn{8}{|c|}{ Particulars (g/kg on DM basis) } \\
\hline Diets & $\mathrm{OM}$ & $\mathrm{CP}$ & $\mathrm{EE}$ & NDF & $\mathrm{ADF}$ & $\mathrm{HC}$ & TA \\
\hline \multicolumn{8}{|c|}{ Berseem-containing diets } \\
\hline $\operatorname{HFD}(80 \mathrm{R}: 20 \mathrm{C})$ & 842.6 & 110.8 & 27.0 & 541.4 & 357.3 & 184.0 & 157.4 \\
\hline MFD (50R : 50C) & 859.0 & 168.0 & 32.6 & 502.2 & 264.9 & 237.3 & 141.0 \\
\hline LFD (20R: 80C) & 876.9 & 229.8 & 37.9 & 386.2 & 199.9 & 186.3 & 123.1 \\
\hline \multicolumn{8}{|c|}{ Sorghum-containing diets } \\
\hline $\operatorname{HFD}(80 \mathrm{R}: 20 \mathrm{C})$ & 893.4 & 115.5 & 18.5 & 575.2 & 391.4 & 183.8 & 106.6 \\
\hline MFD (50R : 50C) & 900.0 & 178.1 & 22.6 & 422.6 & 290.1 & 132.5 & 100.0 \\
\hline LFD (20R : 80C) & 901.9 & 196.3 & 35.2 & 279.0 & 192.2 & 86.8 & 98.1 \\
\hline
\end{tabular}

OM: organic matter; CP: crude protein; EE: ether extract; NDF: neutral detergent fiber; ADF: Acid detergent fiber; HC: hemicellulose; TA: total ash. HFD: high-fiber diet; MFD: medium-fiber diet; LFD: low-fiber diet; R: roughage; C: concentrate.

* Roughage part composed of wheat straw (70 parts) and sorghum (30 parts) or berseem (30 parts).

2.9. In Vitro True DM Degradability, Proximate Principles, and Cell Wall Constituents. To estimate in vitro true DM, degradability of feed sample in each syringe was estimated after end of incubation period [12]. The proximate principles [13] and cell wall constituents [14] were also estimated for substrate.

2.10. Statistical Analysis. Experimental data of different parameters were analyzed in $4 \times 3$ with three replicates factorial arrangement in randomized block design with three replicates for analysis of variance [15]. The effects of different diet and doses of fumaric compared with control were tested using the factorial arrangement in complete randomized block design in OPSTAT statistical software developed by Chaudhry Chran Singh Haryana Agriculture University, Hissar, Haryana, India. When the overall F-test was significant, differences between means and the control were declared significant at $P \leq 0.05$ using the Fisher's Least Significant Difference (Critical Difference).

\section{Results}

The chemical composition of different diets was presented in Table 1. As expected, the CP and NDF contents were increased with increasing the level of roughage in diets. Ether extract was also found highest in LFD (60C: 40R) and lowest in HFD (40C:60R). The effects of fumaric acid addition on in vitro rumen fermentation pattern and methane production of different diets were shown in Table 2 to Table 5, respectively. In all treatment combinations, the $\mathrm{pH}$ was remained relatively stable at near range in sorghum-based diets and in berseem-based diets and statistically remained similar in all diets. Results of digestible dry matter (DDM) were increased by addition of fumaric acid mainly in diets containing berseem; however, DDM values almost remained similar in sorghum-based diets. The maximum DM digestibility values were noticed in low-fiber diets at $10 \mathrm{mM}$ dose. DM digestibility values were found significantly $(P \leq$ 0.05 ) increased at $5 \mathrm{mM}$ and $10 \mathrm{mM}$ dose of fumaric acid in all type of diets; however, at $15 \mathrm{mM}$ dose, a reduction of
DM digestibility was found in all high-, medium-, and lowfiber diets, respectively (Table 2). Similarly, the PF and MBM values were increased $(P \leq 0.05)$ with supplementation of fumaric acid at different concentration in all dietary treatment combinations in berseem-based diets. The differences of PF and MBM values among different doses of fumaric acid and diets were found significant $(P \leq 0.05)$. The results related with methane production showed decreasing trend due to fumaric acid supplementation in high-, medium-, and low-fiber berseem-based diets, respectively. Methane $(\mathrm{mL} / \mathrm{g}$ DM) reduced from 44.08 to 22.45 in HFD, 53.68 to 27.18 in MFD, and 58.61 to 30.66 in LFD, respectively. The similar trend was noticed in case of methane $(\mathrm{mM} / \mathrm{g} \mathrm{DM})$ which was also significantly $(P \leq 0.05)$ reduced in different treatment combinations in all the three berseem-based diets (Table 2). In case of methane, the maximum decrease was noticed at $15 \mathrm{mM}$ in $\mathrm{HFD}$, and similar in case of MFD; however, in LFD, maximum reduction was found at $5 \mathrm{mM}$ dose in comparison to other doses of fumaric acid. The values of methane ( $\mathrm{mL} / \mathrm{g} \mathrm{DM}$ and $\mathrm{mM} / \mathrm{g} \mathrm{DM})$ among treatment and diets found to be significantly different at $P \leq 0.05$. The results with respect to VFA production indicated that TVFA concentration was increased due to addition of fumaric acid at different concentration in all diets and maximum value was noticed at $15 \mathrm{mM}$ dose in LFD and the minimum value was noticed at $5 \mathrm{mM}$ dose in HFD in all the diets. TVFA content increased significantly at all levels of fumaric acid supplementation in high-, medium-, and low-fiber berseembased diets in comparison to control (Table 3 ). The value of acetate production remained similar in all the diets; however, propionate production was significantly increased $(P \leq 0.05)$ by supplementation of fumaric acid at different concentrations in all berseem-based diets. The propionic acid production ranges from 1.00 to $2.41 \mathrm{mM} / 100 \mathrm{~mL}$ in different dietary treatment combinations, and the maximum values were noticed at highest concentration of fumaric acid, that is, $15 \mathrm{mM}$ in comparison to other concentration of fumaric acid and differences between berseem-based diets and treatments were statistically significant $(P \leq 0.05)$. The $A$ : $P$ ratio was also decreased with increase in concentration of fumaric acid in most of treatment combinations in berseem-based diets (Figure 1). Butyric acid was significantly 
TABLE 2: Supplementation effect of fumaric acid on digestibility in sorghum containing diets.

\begin{tabular}{|c|c|c|c|c|c|c|c|c|c|}
\hline \multicolumn{10}{|c|}{ Parameters } \\
\hline $\begin{array}{l}\text { Sorghum-containing } \\
\text { diets }\end{array}$ & $\begin{array}{l}\text { Dose } \\
(\mathrm{mM})\end{array}$ & $\mathrm{pH}$ & $\begin{array}{l}\mathrm{DDM} \\
(\mathrm{mg})\end{array}$ & $\begin{array}{c}\mathrm{PF} \\
\text { (mg TDMD } / \mathrm{mL} \\
\text { gas) }\end{array}$ & $\begin{array}{c}\mathrm{MBM} \\
(\mathrm{mg})\end{array}$ & $\begin{array}{c}\mathrm{CH}_{4} \\
\text { (mL/gm DM } \\
\text { incubated) }\end{array}$ & $\begin{array}{c}\mathrm{CH}_{4} \\
(\mathrm{mM} / \mathrm{g} \mathrm{DM})\end{array}$ & $\begin{array}{c}\mathrm{NH}_{3}-\mathrm{N} \\
(\mathrm{mg} / 100 \mathrm{~mL})\end{array}$ & $\begin{array}{c}\text { Protozoa } \\
\left(\times 10^{4} \mathrm{~mL}^{-1}\right)\end{array}$ \\
\hline \multirow{4}{*}{ HFD (80R:20C) } & 0 & 7.13 & 133.00 & 4.07 & 59.50 & 39.07 & 3.88 & 19.13 & 2.50 \\
\hline & 5 & 7.19 & 135.33 & 4.59 & 68.96 & 33.32 & 3.31 & 21.47 & 1.50 \\
\hline & 10 & 7.13 & 133.33 & 4.00 & 58.33 & 30.62 & 3.05 & 16.80 & 1.25 \\
\hline & 15 & 7.15 & 118.00 & 4.00 & 51.63 & 27.26 & 2.71 & 20.07 & 1.25 \\
\hline \multirow{4}{*}{ MFD (50R: 50C) } & 0 & 7.14 & 150.00 & 3.80 & 61.13 & 45.68 & 4.55 & 24.27 & 1.63 \\
\hline & 5 & 7.19 & 148.67 & 4.21 & 69.17 & 38.72 & 3.85 & 20.07 & 1.75 \\
\hline & 10 & 7.24 & 148.33 & 4.03 & 65.46 & 34.86 & 3.47 & 26.13 & 1.75 \\
\hline & 15 & 7.15 & 139.33 & 3.89 & 58.71 & 33.46 & 3.33 & 20.07 & 0.75 \\
\hline \multirow{4}{*}{ LFD (20R: 80C) } & 0 & 7.21 & 157.67 & 3.73 & 62.42 & 49.72 & 4.94 & 27.53 & 0.75 \\
\hline & 5 & 7.16 & 158.00 & 3.97 & 68.38 & 42.77 & 4.25 & 24.27 & 0.50 \\
\hline & 10 & 7.15 & 159.00 & 3.91 & 67.50 & 37.83 & 3.76 & 22.40 & 1.00 \\
\hline & 15 & 7.14 & 156.33 & 4.15 & 71.58 & 35.66 & 3.55 & 28.00 & 1.50 \\
\hline \multirow{3}{*}{ SEM } & Diets (D) & NS & 1.55 & 0.04 & 1.29 & 0.33 & 0.03 & 1.09 & NS \\
\hline & Treatments $(\mathrm{T})$ & NS & 1.79 & 0.05 & 1.49 & 0.39 & 0.04 & NS & NS \\
\hline & $\mathrm{D} \times \mathrm{T}$ & NS & NS & 0.09 & 2.59 & NS & NS & NS & NS \\
\hline
\end{tabular}

HFD: high-fiber diet; MFD: medium-fiber diet; LFD: low-fiber diet; R: roughage; C: concentrate; DDM: digestible dry matter (mg); PF: partition factor (mg TDMD/mL gas); MBM: microbial biomass (mg); SEM: standard error of means.

TABLE 3: Supplementation effect of fumaric acid on rumen fermentation in Sorghum containing diets.

\begin{tabular}{|c|c|c|c|c|c|}
\hline $\begin{array}{l}\text { Sorghum containing } \\
\text { diets }\end{array}$ & Dose & TVFA (mM) & Acetate $(\mathrm{mM})$ & Propionate (mM) & Butyrate $(\mathrm{mM})$ \\
\hline \multirow{4}{*}{ HFD (80R : 20C) } & 0 & 51.5 & 34.2 & 11.1 & 6.3 \\
\hline & 5 & 62.7 & 39.8 & 16.2 & 6.7 \\
\hline & 10 & 63.0 & 38.7 & 18.1 & 6.3 \\
\hline & 15 & 66.2 & 40.0 & 19.9 & 6.3 \\
\hline \multirow{4}{*}{ MFD (50R : 50C) } & 0 & 61.8 & 40.4 & 14.5 & 7.0 \\
\hline & 5 & 58.8 & 38.5 & 15.3 & 5.0 \\
\hline & 10 & 68.2 & 43.4 & 19.4 & 5.4 \\
\hline & 15 & 71.5 & 42.2 & 22.1 & 7.2 \\
\hline \multirow{4}{*}{ LFD (20R: 80C) } & 0 & 64.5 & 43.8 & 12.7 & 7.9 \\
\hline & 5 & 70.3 & 43.2 & 19.5 & 7.6 \\
\hline & 10 & 71.0 & 42.4 & 21.5 & 7.1 \\
\hline & 15 & 72.7 & 41.9 & 23.0 & 7.7 \\
\hline \multirow{3}{*}{ SEM } & Diet $(\mathrm{D})$ & 1.04 & 0.69 & 0.45 & 0.19 \\
\hline & Treatment (T) & 1.20 & NS & 0.52 & 0.22 \\
\hline & $\mathrm{D} \times \mathrm{T}$ & NS & 1.38 & NS & 0.04 \\
\hline
\end{tabular}

HFD: high-fiber diet; MFD: medium-fiber diet; LFD: low-fiber diet; R: roughage; C: concentrate; TVFA, total volatile fatty acids (mM); H: hydrogen; SEM: standard error of means.

decreased due to fumaric acid supplementation in all diets, and the lowest concentration was found in case of HFD and highest concentration in case of LFD. The differences of butyrate production among the diet in different treatment remained statistically significant at $P \leq 0.05$. Ammonia nitrogen and protozoal number was also decreased due to supplementation of fumaric acid in different dietary treatment combinations, and differences among the treatments were statistically significant at 5\% (Table 3 ).

Results of sorghum-based diets are presented in Tables 4 and 5, and the results of in vitro study indicated that values of IVDDM were significantly reduced at $15 \mathrm{mM}$ in
HFD in comparison to other treatment combinations in medium and low-fiber sorghum-based diets. In HFD, DDM was significantly $(P \leq 0.05)$ decreased from $133.00 \mathrm{mg}$ in control to $118.00 \mathrm{mg}$ at $15 \mathrm{mM}$ dose.

The PF and MBM yield were increased significantly $(P \leq$ 0.05 ) with fumaric acid supplementation at different doses in all dietary treatment combinations (Table 4). In HFD, highest PF (4.59) and highest MBM yield $(68.96 \mathrm{mg})$ was found at $5 \mathrm{mM}$ dose, as compared to control PF (4.07) and MBM yield (59.50 mg). In MFD, PF and MBM yield was also found highest at $5 \mathrm{mM}$ dose, the $\mathrm{PF}$ and $\mathrm{MBM}$ yield was 3.80 and $61.13 \mathrm{mg}$ (in control) and 4.21 and $69.17 \mathrm{mg}$ at $5 \mathrm{mM}$ 
TABLE 4: Supplementation effect of fumaric acid on digestibility in berseem-containing diets.

\begin{tabular}{|c|c|c|c|c|c|c|c|c|c|}
\hline \multicolumn{10}{|c|}{ Parameters } \\
\hline $\begin{array}{l}\text { Berseem-containing } \\
\text { diets }\end{array}$ & $\begin{array}{l}\text { Dose } \\
(\mathrm{mM})\end{array}$ & $\mathrm{pH}$ & $\begin{array}{l}\mathrm{DDM} \\
(\mathrm{mg})\end{array}$ & $\begin{array}{c}\mathrm{PF} \\
(\mathrm{mg} \mathrm{TDMD} / \mathrm{mL} \\
\text { gas })\end{array}$ & $\begin{array}{l}\mathrm{MBM} \\
(\mathrm{mg})\end{array}$ & $\begin{array}{c}\mathrm{CH}_{4} \\
\text { (mL/gm DM } \\
\text { incubated) }\end{array}$ & $\begin{array}{c}\mathrm{CH}_{4} \\
(\mathrm{mM} / \mathrm{g} \mathrm{DM})\end{array}$ & $\begin{array}{c}\mathrm{NH}_{3}-\mathrm{N} \\
(\mathrm{mg} / 100 \mathrm{~mL})\end{array}$ & $\begin{array}{c}\text { Protozoa } \\
\left(\times 10^{4} \mathrm{~mL}^{-1}\right)\end{array}$ \\
\hline \multirow{4}{*}{ HFD (80R:20C) } & 0 & 7.20 & 100.33 & 2.85 & 21.21 & 44.08 & 4.38 & 22.87 & 2.58 \\
\hline & 5 & 7.20 & 130.33 & 4.58 & 65.84 & 26.23 & 2.61 & 14.47 & 2.83 \\
\hline & 10 & 7.19 & 134.33 & 4.94 & 73.21 & 24.19 & 2.40 & 15.40 & 0.92 \\
\hline & 15 & 7.14 & 118.00 & 5.39 & 67.38 & 22.45 & 2.23 & 15.87 & 1.25 \\
\hline \multirow{4}{*}{ MFD (50R: 50C) } & 0 & 7.17 & 105.33 & 2.47 & 9.33 & 53.68 & 5.34 & 21.00 & 2.58 \\
\hline & 5 & 7.15 & 145.33 & 4.74 & 76.34 & 30.16 & 3.00 & 19.60 & 1.42 \\
\hline & 10 & 7.23 & 140.00 & 4.44 & 69.13 & 29.15 & 2.90 & 17.27 & 1.50 \\
\hline & 15 & 7.16 & 126.67 & 4.84 & 66.67 & 27.18 & 2.70 & 20.07 & 1.92 \\
\hline \multirow{4}{*}{ LFD (20R: 80C ) } & 0 & 7.26 & 137.33 & 2.99 & 33.84 & 58.61 & 5.83 & 27.07 & 2.83 \\
\hline & 5 & 7.19 & 139.67 & 4.64 & 70.67 & 30.66 & 3.05 & 23.80 & 0.83 \\
\hline & 10 & 7.18 & 158.00 & 4.48 & 78.50 & 31.07 & 3.09 & 22.40 & 1.42 \\
\hline & 15 & 7.18 & 120.67 & 3.54 & 44.42 & 35.72 & 3.55 & 22.87 & 1.25 \\
\hline \multirow{3}{*}{ SEM } & Diet (D) & NS & 4.46 & NS & NS & 1.45 & 0.14 & 0.32 & NS \\
\hline & Treatment $(\mathrm{T})$ & NS & 5.15 & 0.19 & 4.96 & 1.67 & 0.17 & 0.37 & 0.27 \\
\hline & $\mathrm{D} \times \mathrm{T}$ & NS & NS & NS & NS & NS & NS & 0.64 & NS \\
\hline
\end{tabular}

HFD: high-fiber diet; MFD: medium-fiber diet; LFD: low-fiber diet; R: roughage; C: concentrate; DDM: digestible dry matter (mg); PF: partition factor (mg $\mathrm{TDMD} / \mathrm{mL}$ gas); MBM: microbial biomass (mg); SEM: standard error of means.

TABLE 5: Supplementation effect of fumaric acid on rumen fermentation in berseem-containing diets.

\begin{tabular}{|c|c|c|c|c|c|}
\hline $\begin{array}{l}\text { Berseem- } \\
\text { containing } \\
\text { diets }\end{array}$ & Dose & TVFA (mM) & Acetate $(\mathrm{mM})$ & Propionate (mM) & Butyrate $(\mathrm{mM})$ \\
\hline \multirow{4}{*}{ HFD (80R : 20C) } & 0 & 51.5 & 36.1 & 10.0 & 5.4 \\
\hline & 5 & 53.2 & 34.8 & 13.7 & 4.7 \\
\hline & 10 & 58.8 & 36.8 & 17.3 & 4.8 \\
\hline & 15 & 61.3 & 37.5 & 19.1 & 4.7 \\
\hline \multirow{4}{*}{ MFD (50R: 50C) } & 0 & 57.0 & 40.0 & 10.6 & 6.5 \\
\hline & 5 & 55.7 & 35.5 & 15.2 & 4.9 \\
\hline & 10 & 60.5 & 38.1 & 16.7 & 5.7 \\
\hline & 15 & 59.5 & 35.3 & 19.1 & 5.2 \\
\hline \multirow{4}{*}{ LFD (20R : 80C) } & 0 & 58.2 & 39.6 & 11.0 & 7.6 \\
\hline & 5 & 54.0 & 35.4 & 13.4 & 5.2 \\
\hline & 10 & 65.5 & 39.2 & 20.5 & 5.9 \\
\hline & 15 & 73.3 & 42.7 & 24.1 & 6.5 \\
\hline \multirow{3}{*}{ SEM } & $\operatorname{Diet}(\mathrm{D})$ & 1.42 & NS & 0.49 & 0.15 \\
\hline & Treatment $(\mathrm{T})$ & 1.64 & NS & 0.56 & 0.18 \\
\hline & $\mathrm{D} \times \mathrm{T}$ & NS & NS & 0.98 & NS \\
\hline
\end{tabular}

HFD: high-fiber diet; MFD: medium-fiber diet; LFD: low-fiber diet; R: roughage; C: concentrate; TVFA: total volatile fatty acids (mM); H: hydrogen; SEM: standard error of means.

dose, respectively. But in case of LFD, highest PF and MBM yield was found at $15 \mathrm{mM}$ dose and it was 4.15 and $71.58 \mathrm{mg}$, respectively. A significant methane reduction was seen in all types of diet and treatment combinations due to addition of fumaric acid in sorghum-based diets. In HFD, methane (mL/gm DM) reduced from $39.07 \mathrm{~mL}$ to $27.26 \mathrm{~mL}$ in HFD, $45.68 \mathrm{~mL}$ to $33.46 \mathrm{~mL}$ in MFD, and $49.72 \mathrm{~mL}$ to $35.66 \mathrm{~mL}$ in LFD. Similar trend in methane reduction was also noticed in methane (mM/g DM). A significant effect of fumaric acid supplementation in sorghum-based diets was found on TVFA $(\mathrm{mM} / 100 \mathrm{~mL})$ concentration. In HFD, MFD, and LFD, the highest concentration of TVFA was found at $15 \mathrm{mM}$ dose, that is, $6.62,7.15$, and $7.27 \mathrm{mM}$, respectively. Acetate concentration $(\mathrm{mM} / 100 \mathrm{~mL})$ did not differ significantly among treatment diets, whereas propionate $(\mathrm{mM} / 100 \mathrm{~mL})$ concentration was increased significantly $(P<0.05)$ due 

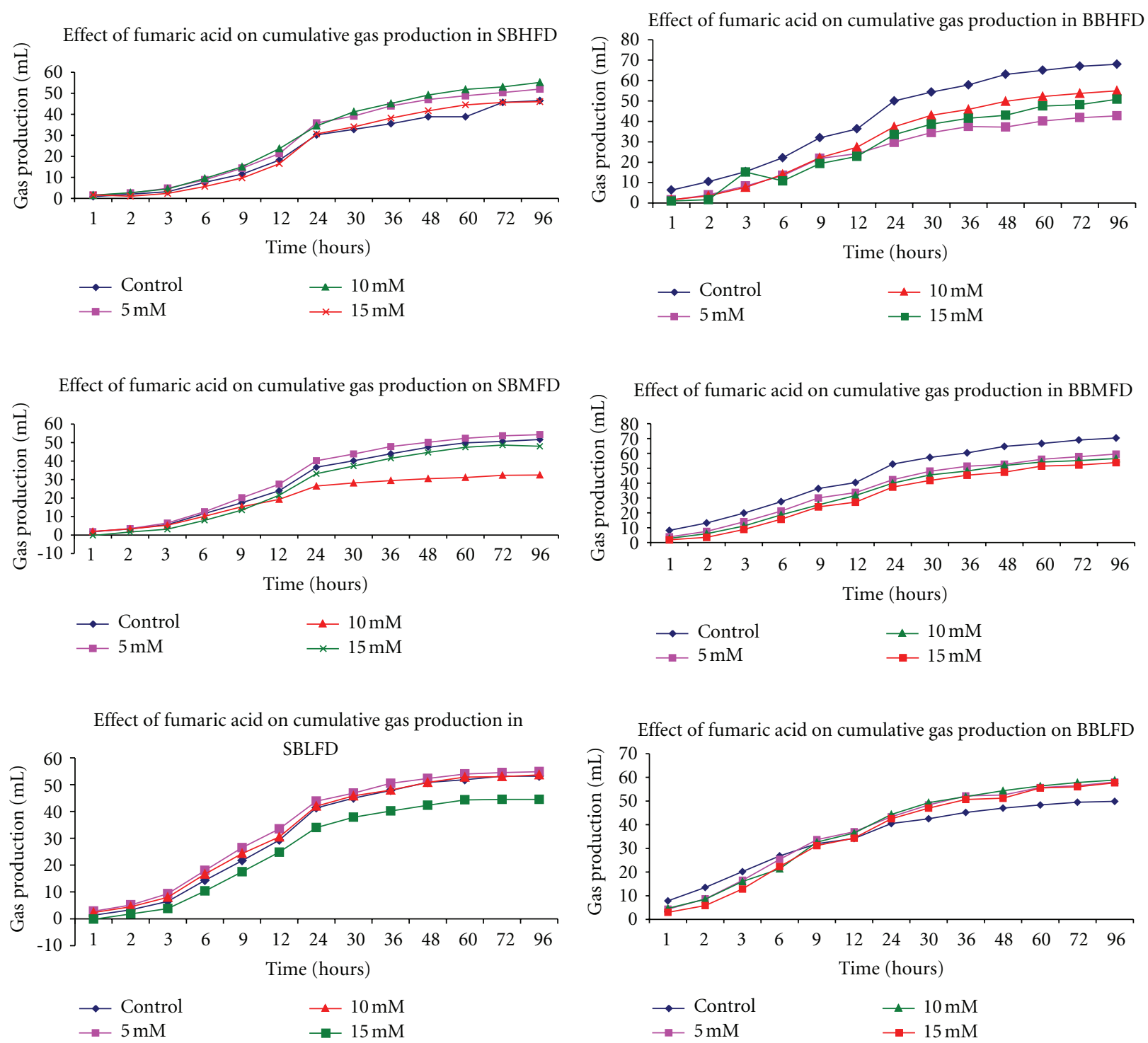

(a) HFSCD: high-fiber sorghum containing diet; MFSCD: mediumfiber sorghum containing diet; LFSCD: low-fiber sorghum containing diet

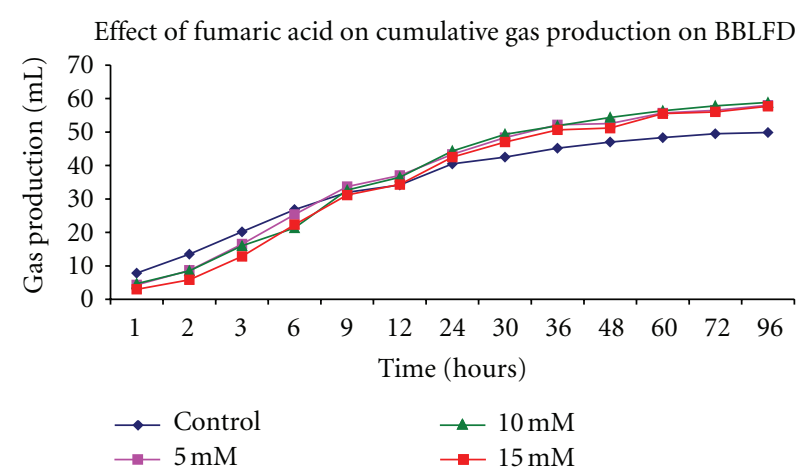

(b) HFBCD: high-fiber berseem containing diet; MFBCD: mediumfiber berseem containing diet: LFBCD: low-fiber berseem containing diet

FIgURE 1: Fumaric acid supplementation effect on cumulative gas production in high-, medium-, and low-fiber sorghum- and berseemcontaining diets during $96 \mathrm{~h}$ in vitro incubations.

to fumaric acid supplementation (Table 3 ). The butyric acid $(\mathrm{mM} / 100 \mathrm{~mL})$ concentration was significantly decreased due to fumaric acid treatment in all three diets; lowest concentration was found in HFD, and highest was found in LFD. A significant decrease in $\mathrm{NH}_{3}-\mathrm{N}$ concentration $(\mathrm{mg} / 100 \mathrm{~mL})$ was observed due to fumaric acid treatment. In $\mathrm{HFD}$, the highest decrease in $\mathrm{NH}_{3}-\mathrm{N}$ concentration was at $10 \mathrm{mM}$ dose, that is, 19.13 to $16.80 \mathrm{mg} / 100 \mathrm{~mL}$, in MFD, highest decrease was at 5 and $15 \mathrm{mM}$ dose that is, 24.27 to $20.07 \mathrm{mg} / 100 \mathrm{~mL}$, and, in LFD, it was at $10 \mathrm{mM}$ dose, that is, 27.53 to $22.40 \mathrm{mg} / 100 \mathrm{~mL}$. Protozoal number also decreased significantly $(P \leq 0.05)$ due to fumaric acid supplementation in different dietary treatment combinations in sorghum based diets.

Results related to gas kinetics in sorghum- and berseembased diets presented in Table 6 . Potential gas production $(b)$ was increased due to addition of fumaric acid in sorghumbased diets, and increase was noticed up to $10 \mathrm{mM}$ of fumaric acid supplementation. Similarly, the gas production rate constant $(c)$ also increased in treatment combinations in comparison to control in high-, medium-, and low-fiber sorghumbased diets. The $b$ values range from 32.18 to $57.11 \mathrm{~mL}$ in sorghum-based diets, but in case of berseem-based diets, the $b$ values decreased with supplementation of fumaric acid at 
TABLE 6: Effect of fumaric acid on gas kinetics $(96 \mathrm{~h})$ in sorghum- and berseem-containing diets.

\begin{tabular}{|c|c|c|c|c|c|c|c|c|c|c|c|c|}
\hline \multicolumn{9}{|c|}{ Regression model Orskov and Macdonald without lag } & \multirow{2}{*}{\multicolumn{4}{|c|}{$\begin{array}{cl}\text { Equation: } & F=b \times(1-\exp (-c \times x)) \\
& \text { LFD }(20 \mathrm{R}: 80 \mathrm{C})\end{array}$}} \\
\hline \multirow{2}{*}{$\begin{array}{l}\text { Diet type } \\
\text { Dose } \\
(\mathrm{mM})\end{array}$} & \multicolumn{4}{|c|}{ HFD ( 80R: 20C) } & \multicolumn{4}{|c|}{ MFD ( 50R:50C) } & & & & \\
\hline & 0 & $5 \mathrm{mM}$ & $10 \mathrm{mM}$ & $15 \mathrm{mM}$ & 0 & $5 \mathrm{mM}$ & $10 \mathrm{mM}$ & $15 \mathrm{mM}$ & 0 & $5 \mathrm{mM}$ & $10 \mathrm{mM}$ & $15 \mathrm{mM}$ \\
\hline \multicolumn{13}{|c|}{ Sorghum diet } \\
\hline$b$ & 47.423 & 53.815 & 57.114 & 49.999 & 52.762 & 55.059 & 32.180 & 51.193 & 53.990 & 54.610 & 53.636 & 45.779 \\
\hline$c$ & 0.037 & 0.042 & 0.039 & 0.0351 & 0.048 & 0.052 & 0.069 & 0.041 & 0.058 & 0.070 & 0.064 & 0.055 \\
\hline$R^{2}$ & 0.990 & 0.993 & 0.994 & 0.984 & 0.998 & 0.996 & 0.997 & 0.989 & 0.995 & 0.997 & 0.998 & 0.989 \\
\hline \multicolumn{13}{|c|}{ Berseem diet } \\
\hline$b$ & 65.945 & 40.854 & 54.731 & 49.620 & 66.459 & 56.360 & 54.919 & 52.590 & 46.454 & 54.463 & 56.077 & 54.699 \\
\hline$c$ & 0.066 & 0.068 & 0.052 & 0.050 & 0.082 & 0.073 & 0.064 & 0.057 & 0.138 & 0.095 & 0.084 & 0.079 \\
\hline$R^{2}$ & 0.992 & 0.986 & 0.997 & 0.975 & 0.981 & 0.987 & 0.994 & 0.994 & 0.961 & 0.981 & 0.987 & 0.986 \\
\hline
\end{tabular}

$b$ : potential gas production $(\mathrm{mL}) ; c$ : gas production rate constant $(\mathrm{mL} / \mathrm{h}) ; R^{2}$ : regression coefficient; HFD: high-fiber diet; MFD: medium-fiber diet; LFD: low-fiber diet; R: roughage; C: concentrate.

different concentration in comparison to control except in low-fiber diet. The gas production rate (c) decreased after fumaric acid treatment. In berseem-based diets, $b$ value ranges from 40.85 to $66.46 \mathrm{~mL}$ and $c$ values from 0.05 to $0.138 \mathrm{~mL} / \mathrm{h}$, respectively.

\section{Discussion}

Results of the study revealed that effect of fumaric acid was dependent on nature of diets as seen with the digestible dry matter which increased in most of the treatment combinations with berseem-containing diets but effect was negligible with sorghum-based diets but little reduction in digestibility was noticed at high concentration $(15 \mathrm{mM})$ of fumaric addition. The present findings were more or less in accordance with the studies in which increased digestibility of DM with fumaric acid and other organic acids in different diets were reported [5]. The main reason for improvement in digestibility might be due to increase in number of cellulolytic organisms which were benefited from the presence of methanogenic or other $\mathrm{H}_{2}$ utilizing bacteria as a result of interspecies $\mathrm{H}_{2}$ transfer [16]. Further, if hydrogen removal or uptake was increased by the addition of propionate precursors or dicarboxylic acids which might stimulate the growth of fibrolytic bacteria and hence enhance cellulose digestion $[1,3]$. The addition of fumarate at different concentration in both diets (berseem and sorghum) resulted in significantly increased propionate production with different ratio of roughage and concentrate. Maximum concentration of propionate was observed at higher dosage of fumaric acid than lower dosages. Similar results were reported in different studies with organic acid supplementation $[3,5,17,18]$.These studies clearly indicated that fumaric acid provides an electron sink for metabolic hydrogen and helps in more propionic acid production. The addition of fumarate not only decreases $\mathrm{CH}_{4}$ production but also increased propionate, succinate, or both and slightly increased acetate and butyrate $[2,3]$.

In present study, methane reduction was found maximum in all three types of berseem-containing diets than the sorghum diets. The conversion of glucose to acetate, propio- nate, and butyrate in the rumen results in an overall net release of reducing power. Much of this is used by methanogenic archaea to reduce $\mathrm{CO}_{2}$ to $\mathrm{CH}_{4}$, but $\mathrm{H}_{2}$ can also be used as a substrate in fumarate reduction [19]. As result $\mathrm{H}$ is used to reduce fumarate, there is a decrease in the availability of $\mathrm{H}$ for methanogenesis in the rumen which could decrease methane production. Fumarate, in the present study, found significantly $(P \leq 0.05)$ decreased methane production with all substrates in different ratio of roughage to concentrate, but the ability of methane reduction varies depending upon concentration of fumarate and type of diet $[3,20]$. Ammonia concentration in present study was decreased due to addition of fumarate in most of the treatment combinations [20]. The $\mathrm{PF}$ of the diets is known as an index of microbial biomass synthesis efficiency [7], and the diet formulation to achieve higher PF would mean aiming for higher MBME in vivo $[21,22]$. In present experiment, berseem-based diets had significant improvement effect on MBM yield which might be easily correlated with decrease ammonia concentration after addition of fumaric acid which means higher uptake of ammonia by mixed ruminal bacteria for microbial protein synthesis. Moreover, results of the gas kinetics showed that potential gas production was increased in sorghum-based diets but decreased in berseem-based diets correspondingly. The rate of gas production increased in sorghum-based diets and decreased in berseem-based diet which also related with digestibility of different diets formulated based on berseem and sorghum.

\section{Conclusions}

Overall, it was concluded from the results of the present study that fumaric acid supplementation in sorghum and berseembased diets in different ratio of roughage to concentrate should able to modulate the rumen fermentation pattern and significantly decreased the methane production by diverting the hydrogen towards propionate production without affecting the digestibility adversely but digestibility of dry matter more or less affected by nature of proximate principles. 


\section{Acknowledgment}

The authors would like to thank and acknowledge for the grant provided by NFBSRA, Ministry of Agriculture, ICAR, New Delhi, to carry out this research work.

\section{References}

[1] N. Asanuma and T. Hino, "Activity and properties of fumarate reductase in ruminal bacteria," Journal of General and Applied Microbiology, vol. 46, no. 3, pp. 119-125, 2000.

[2] N. Asanuma, M. Iwamoto, and T. Hino, "Effect of the addition of fumarate on methane production by ruminal microorganisms in vitro," Journal of Dairy Science, vol. 82, no. 4, pp. 780-787, 1999.

[3] S. López, C. Valdés, C. J. Newbold, and R. J. Wallace, "Influence of sodium fumarate addition on rumen fermentation in vitro," British Journal of Nutrition, vol. 81, no. 1, pp. 59-64, 1999.

[4] E. M. Ungerfeld, S. R. Rust, and R. Burnett, "Use of some novel alternative electron sinks to inhibit ruminal methanogenesis," Reproduction Nutrition Development, vol. 43, no. 2, pp. 189 202, 2003.

[5] C. J. Newbold, S. López, N. Nelson, J. O. Ouda, R. J. Wallace, and A. R. Moss, "Propionate precursors and other metabolic intermediates as possible alternative electron acceptors to methanogenesis in ruminal fermentation in vitro," British Journal of Nutrition, vol. 94, no. 1, pp. 27-35, 2005.

[6] K. Menke and H. Steingass, "Estimation of the energetic feed value obtained from chemical analysis and in vitro gas production using rumen fluid," Animal Research and Development, vol. 28, pp. 7-55, 1988.

[7] M. Blümmel, H. P. S. Makkar, and K. Becker, "In vitro gas production: a technique revisited," Journal of Animal Physiology and Animal Nutrition, vol. 77, no. 1, pp. 24-34, 1997.

[8] E. R. Ørskov and I. McDonald, "The estimation of protein degradability in the rumen from incubation measurements weighted according to rate of passage," The Journal of Agricultural Science, vol. 92, no. 2, pp. 499-503, 1979.

[9] A. John, G. Barnett, and R. L. Reid, "Studies on the production of volatile fatty acids from grass by rumen liquor in an artificial rumen-I. The volatile acid production from fresh grass," The Journal of Agricultural Science, vol. 48, no. 3, pp. 315-321, 1957.

[10] E. S. Erwin, G. J. Marco, and E. M. Emery, "Volatile fatty acid analysis of blood and rumen fluid by gas chromatograph.," Journal of Dairy Science, vol. 44, no. 9, pp. 1768-1771, 1961.

[11] B. A. Dehority, "Evaluation of subsampling and fixation procedures used for counting rumen protozoa," Applied and Environmental Microbiology, vol. 48, no. 1, pp. 182-185, 1984.

[12] P. J. Van Soest, R. H. Wine, and L. A. Moore, "Estimation of the true digestibility of forages by the in vitro digestion of cell walls," in Proceedings of the 10th International Grassland Congress, A. G. G. Hill, Ed., pp. 438-441, Valtioneuvoston Kirjapaino, Helsinki, Finland, 1966.

[13] Association of Official Analytical Chemists, Official Methods of Analysis, chapter 4, AOAC, Arlington, Va, USA, 16th edition, 1995.

[14] P. J. Van Soest, J. B. Robertson, and B. A. Lewis, "Methods for dietary fiber, neutral detergent fiber, and nonstarch polysaccharides in relation to animal nutrition," Journal of Dairy Science, vol. 74, no. 10, pp. 3583-3597, 1991.
[15] G. W. Snedecor and W. G. Cochran, Statistical Methods, Iowa State University Press, Ames, Iowa, USA, 5th edition, 1968.

[16] M. J. Wolin and T. L. Miller, "Microbe-microbe interactions," in The Rumen Microbial Ecosystem, P. N. Hobson and C. S. Stewart, Eds., pp. 467-491, Blackie Academic \& Professional, London, UK, 2nd edition, 1997.

[17] T. R. Callaway and S. A. Martin, "Effects of organic acid and monensin treatment on in vitro mixed ruminal microorganism fermentation of cracked corn," Journal of Animal Science, vol. 74, no. 8, pp. 1982-1989, 1996.

[18] M. D. Carro and M. J. Ranilla, "Effect of the addition of malate on in vitro rumen fermentation of cereal grains," British Journal of Nutrition, vol. 89, no. 2, pp. 181-188, 2003.

[19] J. B. Russell and R. J. Wallace, "Energy-yielding and energy consuming reactions," in The Rumen Microbial Ecosystem, P. N. Hobson and C. S. Stewart, Eds., p. 246, Blackie Academic \& Professional, London, UK, 1997.

[20] K. Bayaru Syuhei and K. Toshihiko, "Effect of fumaric acid on methane production, rumen fermentation and digestibility of cattle fed roughage alone," Animal Science Journal, vol. 72, pp. 139-146, 2001.

[21] M. Blümmel and P. Lebzien, "Predicting ruminal microbial efficiencies of dairy rations by in vitro techniques," Livestock Production Science, vol. 68, no. 2-3, pp. 107-117, 2001.

[22] M. Blümmel, A. Karsli, and J. R. Russell, "Influence of diet on growth yields of rumen miro-organisms in vitro and in vivo: influence on growth yield of variable carbon fluxes to fermentation products," British Journal of Nutrition, vol. 90, no. 3, pp. 625-634, 2003. 

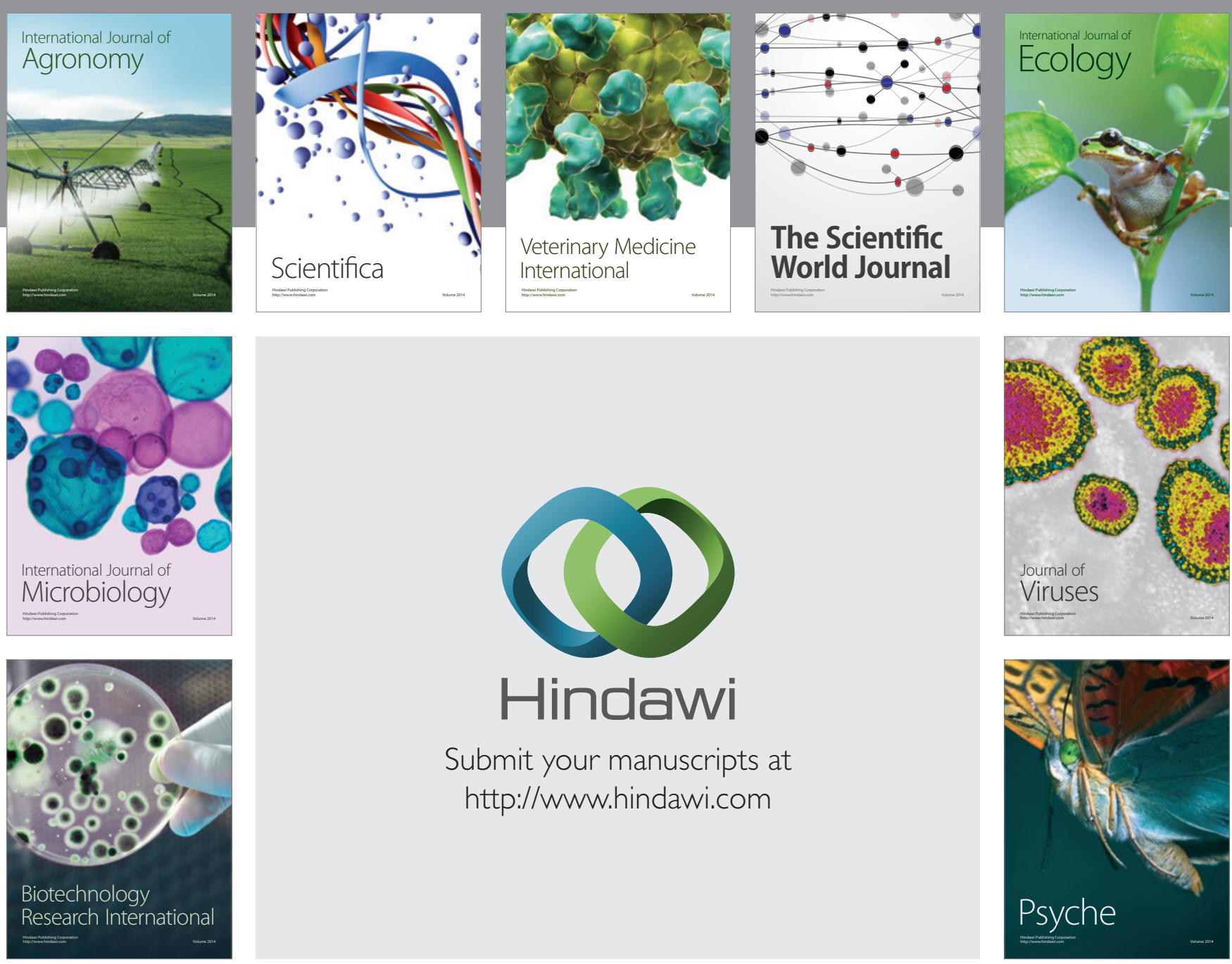

Submit your manuscripts at http://www.hindawi.com
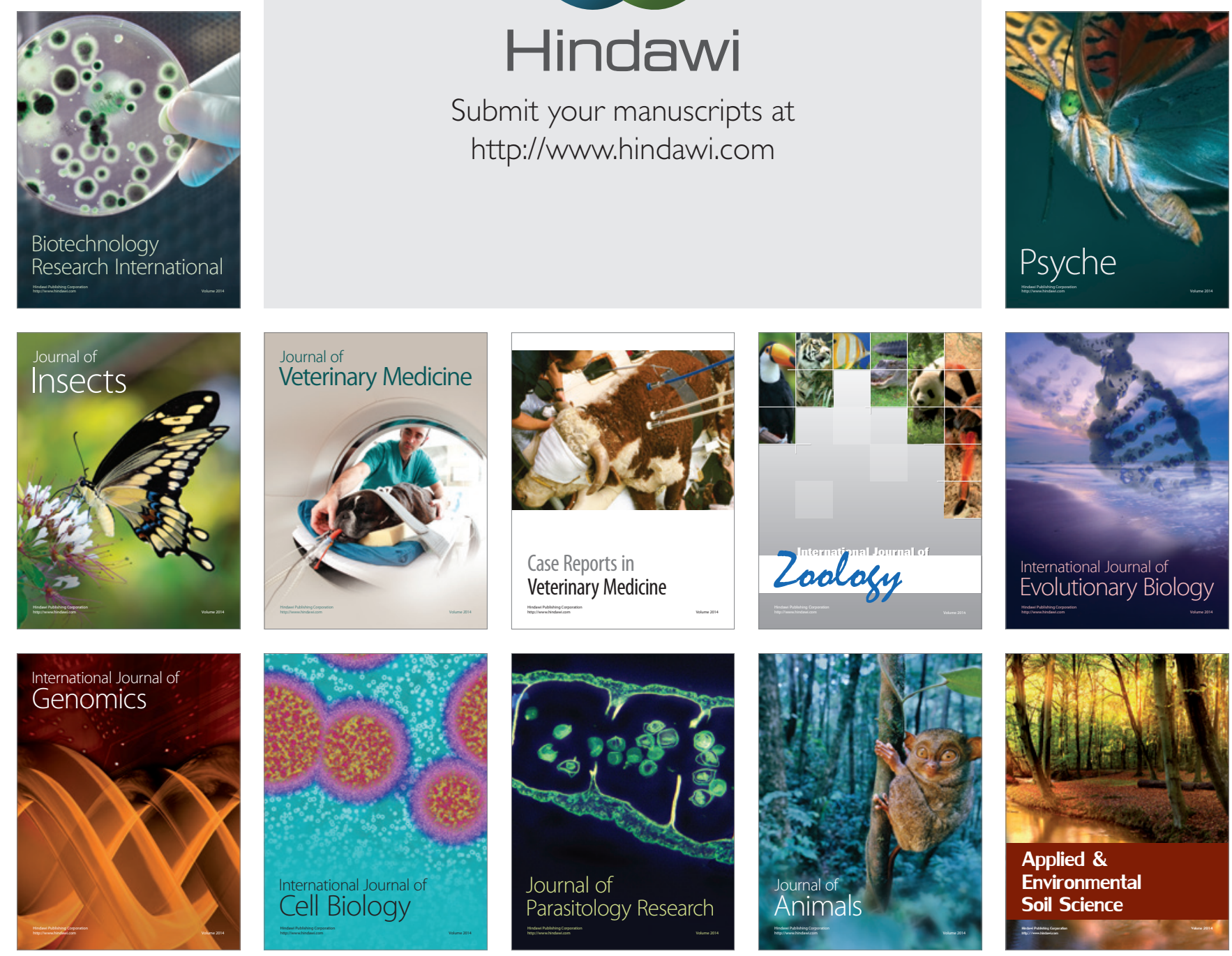